71 巻 707 号 (2005-7)

\title{
RCへリコプタに対するリファレンスガバナの実験による検証*
}

\author{
大原伸 $介^{* 1}$, 平田研二*2, 峯村 紘 史*3
}

\section{Experimental Evaluations of Reference Governors Control Schemes for a RC Helicopter}

\author{
Shinsuke $\mathrm{OH}-\mathrm{HARA}^{* 4}$, Kenji HIRATA and Hiroshi MINEMURA \\ ${ }^{* 4}$ Department of Compute-controlled Mechanical Systems, Osaka University, \\ 2-1 Yamadaoka, Suita-shi, Osaka, 565-0871 Japan
}

\begin{abstract}
This paper investigates experimental evaluations of control schemes for systems with constraints on states and control inputs. Although reference governors are the practical control schemes, the experimental evaluations have been hardly reported. Therefore, it is important to investigate experimental evaluations of reference governors. In this paper, We apply reference governors to a RC (Radio Controlled) model helicopter control system. We design a controller by loop shaping design procedure and construct a closed loop system for the RC model helicopter. We evaluate the effectiveness of reference governors by simulations and experiments.
\end{abstract}

Key Words : Motion Control, Positioning, Nonlinear Control, Reference Governor, Constrained Systems, RC Model Helicopter

1.はじめに

現実の制御系は, 制御対象の保護や物理的な制約等 の理由から数多くの拘束条件を有したシステム，拘束 システムである.このような制御系に対して拘束条件 を考慮せずに制御を行うと, ワインドアップ現象など による制御性能の劣化や制御系の不安定化を招くこと が知られている(1).

拘束システムに対する制御法の一つとして, リファ レンスガバナ ${ }^{(2) ~(9)}$ と呼ばれる手法が近年注目を浴びて いる. リファレンスガバナは, すでに構築された制御 系に対して付加的に用いられる. その役割は与えられ た参照入力を拘束条件を達成するように必要に応じて 整形し，制御系への実際の入力を決定することである.

しかしながら，リファレンスガバナは実際的な制御 法でありながら、これを実システムへ適用した実験に よる検証や考察はあまり行われていない.オフライン で参照入力を整形するリファレンスガバナ(6)(7)(9)は比 較的実装が容易であるため, 実際に実験が行われてい る.ところが, モデル化誤差の影響を顕著に受けてし まい, 拘束条件を大きく破る例も報告されている(7). これに対し，オンラインで参照入力を整形するリファ

* 原稿受付 2004 年 7 月 8 H.

*1 IF. 員. 大阪大学大学院T学研究科(-565-0871 吹田市山田 丘 2 1).

*2 大挭大学大学院 L学研究科。

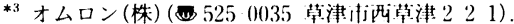

E mail : shinsuke (a newt on.mech.eng.osaka u.ac.jp
レンスガバナ ${ }^{(2)(3)(5)(8)}$ は，毎時刻制御系の状態を観測 して参照入力を整形する. このとき状態の観測により 補正が加わるので, オンライン処理にもとづくリファ レンスガバナは実システムに対して有効であると考え られる．しかしながら実験による検証は，非線形シス テムに対するリファレンスガバナ(3)の場合を除いて, ほとんど報告されていないのが現状である.

そこで本稿では，実機によるリファレンスガバナの検 証を目的とする．本稿で用いる制御対象は，RC(Radio Controlled)へリコプタである. RCへリコプタはブレー ドの回転角度に制限を有する拘束システムである．ま た RCへリコプタのモデルは多くの空気力学パラメー 夕を含み，それらの正確な值を測定することは困難で ある.このため RCへリコプタに対する制御系設計は, 不確かさを含むモデルに対して制御系設計をすること になる. したがって， RCヘリコプタに対してリファレ ンスガバナを適用し，実験により検証することは，モ デル化誤差を含むシステムにおけるリファレンスガバ ナの実用性とその限界を検証することになる．リファ レンスガバナの実機への適用結果がほとんど報告され ていない中で，実験による検証は重要である.

本稿の構成は以下の通りである. 2. では, 拘束条件 が存在する制御系の定式化および本稿で採用するリ ファレンスガバナについて説明する. 3.では, 本稿で 用いる RCへリコプタの機構について説明する. 4. で 
は, RCヘリコプタの 3 軸姿勢運動のモデルの導出方 法を示す．また導出したモデルにもとづき，補償器の 設計を行う．5.では，4. で設計した補償器を実装し， 3 軸姿勢運動の制御の実験を行い，モデルの妥当性お よび拘束条件の影響を検証する. 6. では，筆者らが提 案したリファレンスガバナ ${ }^{(5)(8)}$ と Gilbert らにより提 案されたリファレンスガバナ ${ }^{(2)}$ を実装して実験を行い, その有効性を検証する.

\section{2. 拘束システムとリファレンスガバナ}

ここでは本稿で用いるリファレンスガバナのアルゴ リズムについて説明する.

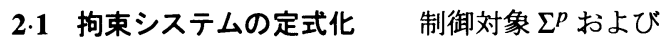
補償器 $\Sigma^{c}$ により構成されるつぎの閉ループ系 $\Sigma$ を考 える.

$$
\begin{aligned}
x(t+1) & =A x(t)+B w(t) \\
\Sigma: \quad z_{0}(t) & =C_{0} x(t)+D_{0} w(t) \\
z_{1}(t) & =C_{1} x(t)
\end{aligned}
$$

ここで $x \in \mathbb{R}^{n}$ は状態， $w \in \mathbb{R}$ は外部からの参照入力, $z_{1} \in \mathbb{R}$ は被制御量であり, ここでの制御目的は外部か らの参照入力 $w$ に対して $z_{1}$ が良好な追従特性を示す ことである. また $z_{0} \in \mathbb{R}^{p_{0}}$ は制御入力および状態に依 存した拘束条件を記述するための変数で

$$
z_{0}(t) \in Z=\left\{z_{0} \in \mathbb{R}^{p_{0}} \mid M_{Z} z_{0} \leq m_{Z}\right\} \quad \forall t \in \mathbb{Z}^{+}
$$

の拘束条件を有するものとする.ここで $\mathbb{Z}^{+}$は非負の 整数を要素とする集合で, $M_{Z} \in \mathbb{R}^{s_{Z} \times p_{0}}, m_{Z} \in \mathbb{R}^{s_{Z}}$ は 集合 $Z$ を規定する線形拘束式を表現する行列である. 実際，拘束条件を有する閉ループ系 $\Sigma$ は，制御対象お よび補償器の状態空間表現から容易に定式化できる.

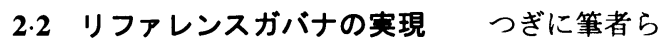

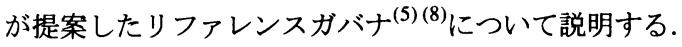

ここでは制御系が拘束条件を破ることなく安全に 動作するための条件を考える. 式 (1) の閉ループ系 $\Sigma$ の忘答は, 適当な初期状態 $x(0)$ と入力の時系列 $w(\cdot) \in W$ で決定される. このとき式 (1b) の応答を $z_{0}(t ; x(0), w(\cdot))$ で表す. 拘束条件の達成とは, すべての 時刻で $z_{0}(t ; x(0), w(\cdot)) \in Z$ が成り立つことである. そ こで以下のように定義される集合, 最大出力許容集合 を考える.

$$
O_{\infty}=\left\{x_{0} \mid z_{0}\left(t ; x_{0}, w(\cdot)\right) \in Z, \forall t \in \mathbb{Z}^{+}, \forall w(\cdot) \in W\right\}
$$

最大出力許容集合 $O_{\infty}$ は, 出力 $z_{0}(t ; x(0), w(\cdot))$ が拘束 条件を達成するような初期状態 $x(0)$ の寸べてからなる 集合である.これより系 $\Sigma$ にどのような入力 $w(\cdot) \in W$
が与えられても， $x(0) \in O_{\infty}$ の成立を調べるだけで，す べての時刻で $z_{0}(t) \in Z$ が成り立つかどうかがわかる. よって， $O_{\infty}$ は拘束システムが安全に動作するための 条件を与える.

ここで $\gamma \geq 0$ により定義される以下の集合を考える.

$$
R^{\gamma}=\{r \in \mathbb{R} \mid-\gamma \leq r \leq \gamma\}
$$

つぎに $W=R^{\gamma}$ のときの最大出力許容集合 $O_{\infty}$ を $O_{\infty}^{\gamma}$ として, 以下のように定める.

$$
O_{\infty}^{\gamma}=\left\{x_{0} \mid z_{0}\left(t ; x_{0}, w(\cdot)\right) \in Z, \forall t \in \mathbb{Z}^{+}, \forall w(\cdot) \in R^{\gamma}\right\}
$$

最大出力許容集合 $O_{\infty}^{\gamma}$ は線形計画法を利用した数值 計算により構成され,

$$
O_{\infty}^{\gamma}=\left\{x \in \mathbb{R}^{n} \quad \mid M x \leq m\right\}
$$

で表現される凸多面体となる. ここで $M \in \mathbb{R}^{s \times n}, m \in \mathbb{R}^{s}$ は $O_{\infty}^{\gamma}$ を規定する線形拘束式を表現する行列である.

ここでは $O_{\infty}^{\gamma} \neq \emptyset$ となるような $\gamma$ に対する $R^{\gamma}$ を参 照入力集合と呼ぶことにする．参照入力集合 $R^{\gamma}$ は $\Sigma$ に対して外部から加えることが許容される参照入力の 大きさを与えることが定義よりわかる.

参照入力集合 $R^{\gamma}$ は制御系に許容される参照入力の 大きさを与えてくれる. しかしながら，拘束条件の存 在のため一般には $R^{\gamma}$ は小さな集合になってしまい, 目 標值が限定されることになる。これは制御の目的から は望ましくないため, 許容される参照入力の集合を拡 大することが必要となる. そこで参照入力集合の拡大 する手順について以下に述べる.

参照入力 $w(t)=\bar{r}$ に対する定常状態を平衡点とする 系 $\Sigma(\bar{r})$ を考える. $w(t)=\bar{r}$ に対する $\Sigma$ の定常状態を

$$
\begin{aligned}
& x_{e}(\bar{r})=(I-A)^{-1} B \bar{r} \\
& z_{0}(\bar{r})=C_{0} x_{e}(\bar{r})+D_{0} \bar{r} \\
& z_{1}(\bar{r})=C_{1} x_{e}(\bar{r})
\end{aligned}
$$

と表す.つぎに $x_{e}(\bar{r})$ を平衡点とする以下の系 $\Sigma(\bar{r})$ を 考える.

$$
\begin{aligned}
\bar{x}(t+1) & =A \bar{x}(t)+B \bar{w}(t) \\
\Sigma(\bar{r}): \quad \bar{z}_{0}(t) & =C_{0} \bar{x}(t)+D_{0} \bar{w}(t) \\
\bar{z}_{1}(t) & =C_{1} \bar{x}(t)
\end{aligned}
$$

ただし $\bar{w}=w-\bar{r}, \bar{x}=x-x_{e}(\bar{r}), \quad \bar{z}_{0}=z_{0}-z_{0}(\bar{r}), \bar{z}_{1}=$ $z_{1}-z_{1}(\bar{r})$ である.このとき系 $\Sigma(\bar{r})$ は

$$
Z(\bar{r})=\left\{\bar{z}_{0} \in \mathbb{R}^{p_{0}} \mid M_{Z}\left(\bar{z}_{0}+z_{0}(\bar{r})\right) \leq m_{Z}\right\}
$$


で定義される集合 $Z(\bar{r})$ に対して $\bar{z}_{0}(t) \in Z(\bar{r}) \forall t \in \mathbb{Z}^{+}$ の拘束条件を有する.ここで $z_{0}(\bar{r})=0$ とすると $Z=$ $Z(\bar{r})$ が成り立つ. そこで本稿では，任意の $\bar{r} に$ 対して $z_{0}(\bar{r})=0$ が成り立つ，と仮定する.この仮定の成立条 件の一つには，制御入力の大きさに関する制約のみを 有する制御系であり，かつ制御対象が積分特性を有す る場合が举げられる ${ }^{(8)}$.

$\Sigma(\bar{r})$ に対する最大出力許容集合と参照入力集合は $\Sigma$ の場合と同様の手順で得られる.ここでは $Z=Z(\bar{r})$ が 成立するので, $\Sigma(\bar{r})$ での最大出力許容集合と参照入力 集合を構成する問題は原点を平衡点にもつ系 $と$ 同じ 問題になる.つまり $(\bar{r})$ に对寸る最大出力許容集合

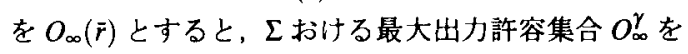
規定する $M \in \mathbb{R}^{s \times n}$ と $m \in \mathbb{R}^{s}$ を用いて

$$
O_{\infty}(\bar{r})=\left\{x \in \mathbb{R}^{n} \mid M\left(x-x_{e}(\bar{r})\right) \leq m\right\}
$$

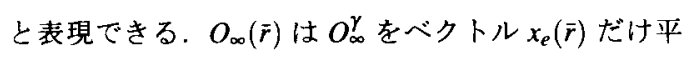
行移動したもので, $x_{e}(\bar{r})=(I-A)^{-1} B \vec{r}$ より

$$
O_{\infty}(\bar{r})=\left\{x \in \mathbb{R}^{n} \mid M x \leq m+M(I-A)^{-1} B \bar{r}\right\}
$$

となる.このようにして，㲹対して最大出力許容集 合をパラメータ化することができる. 参照入力集合も 同様に $\bar{r} に$ 関して以下のようにパラメータ化する。

$$
R(\bar{r})=\{r \in \mathbb{R} \mid-\gamma \leq r-\bar{r} \leq \gamma\}
$$

これよりパラメータ化した参照入力集合, 最大出力 許容集合を利用してリファレンスガバナを構成する. 以下のアルゴリズムにより，制御系への実際の入力で ある $r(t)$ をオンラインで決定する.

リファレンスガパナアルゴリスム 1

$$
\begin{aligned}
& \text { data: } \quad x(t) \in \mathbb{R}^{n} \text { and } w(t) \in \mathbb{R} \\
& \text { determine the optimal solution } \bar{r} \text { of } \\
& \text { minimizing }|w(t)-\tilde{r}| \\
& \text { subject to } M x(t) \leq m+M(I-A)^{-1} B \bar{r} \\
& \text { if } w(t) \in R(\bar{r}): r(t)=w(t) \\
& \text { else if } w(t)>\bar{r}+\gamma: r(t)=\bar{r}+\gamma \\
& \text { else } \quad: r(t)=\bar{r}-\gamma
\end{aligned}
$$

\section{RCヘリコプタの機楼}

ここでは本稿で用いる RCへリコプタ (京商製 EP CONCEPT) の機構について説明する.

$\mathrm{RC}$ リニプタは 4 つの入力を有する. それぞれメ インロータスウオッシュプレートの運動を操作する 3 入力 $\theta_{c}, \theta_{s}, \theta_{0}$ とテイルロータブレードのピッチ角を
操作する 1 入力 $\theta_{t}$ である. 出力である運動は 6 自由 度あり，ロール，ピッチ，ヨーの 3 軸姿勢運動と，鉛 直, 前後, 左右の並進運動である (図 1 参照). 本稿で は, これらのうち 3 軸姿勢運動を対象とする.

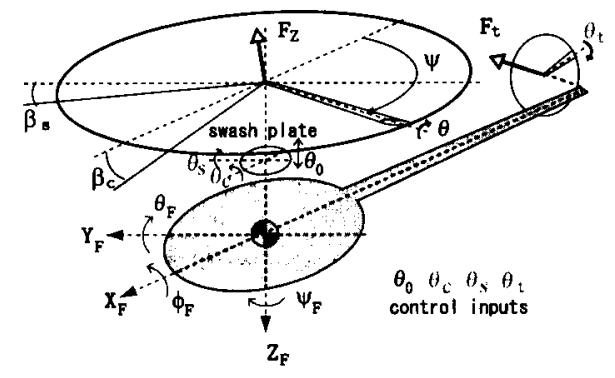

Fig. 1 RC model helicopter configurations.

メインロータ,テールロータへの指令はプロポを介 して行う.したがって，実際の制御入力は， $\theta_{c}, \theta_{s}, \theta_{0}$, $\theta_{t}$ のそれぞれに比例するプロポへの入力電圧 $u_{c}, u_{s}$, $u_{0}, u_{t}$ となる.

この 3 軸姿勢運動に対し運動方程式を導出すると, ロール運動とピッチ運動はヨー運動と非干涉であるこ とがわかる(10).よって制御系設計は，これら2つのシ ステムに対し，独立に行うことにする．また，運動方 程式中の空気力学的パラメータは測定が困難であるこ とから，モデルの導出は，運動方程式の性質と同定実 験の結果を併用して行うことにする.

\section{4. モデルの算出と制御系設㖕}

本節では， RCへリコプタのロール・ピッチ運動お よびヨー運動のモデルを導出し，各モデルに対して， 制御系設計を行う。設計した補償器を実装し，構築し た制御系の検証を行う.

4.1 ヨー通動制御系の權案 ヨー運動モデルを 導出するために周波数応答実験を行う。図 3 は RC リコプタのヨー運動モデルを導出するための実験装置 の概略図である，機体を台座に固定し，ヨ一軸回転角 度をエンコーダにより測定する.その際，信号の読み 取りにはカウンタボード(PCI-6204E Interface 製)を用 いる.なお,プロポには DA ボード(PCI-3338 Interface 製)から直接電圧を供給するように改造した。実験に用 いた計算機は Intel Pentium III 1GHz RT-Linux ver.3.1 である．またサンプリング時間は $1[\mathrm{~ms}]$ である.

ヨー運動のモデルは入力を $u_{t}$, 出力をヨー角 $\psi_{F}$ と する 1 入力 1 出力系になる. 解析的にヨー運動のモデ ルを求めると, 以下の伝達関数で表される.

$$
\frac{\psi_{F}(s)}{u_{t}(s)}=\frac{a_{1}}{s\left(s+a_{2}\right)}
$$




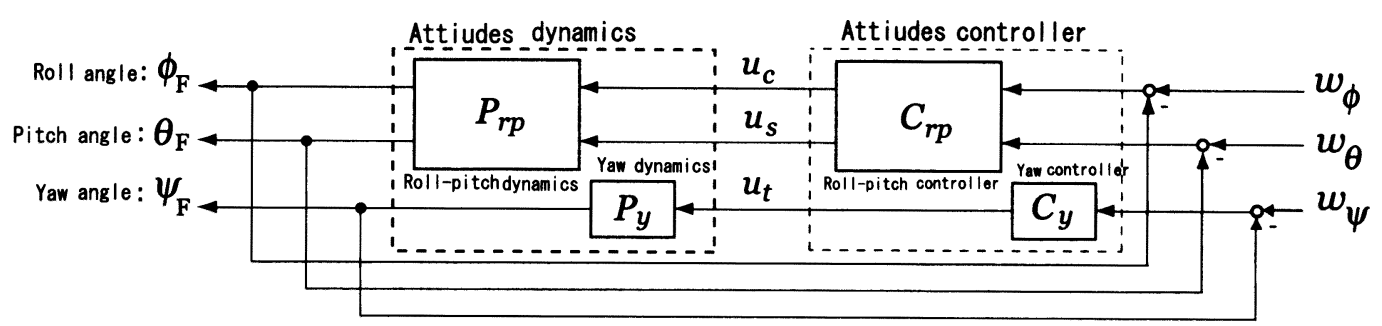

Fig. 2 Control configurations of the RC helicopter.

しかしながら，式 (7) 中の $a_{1}, a_{2}$ は測定困難なパラ メータを多く含む. また積分器を含んでいるため, 開 ループでの周波数応答実験は困難になると考えられる. そこで本稿では, 適当な補償器で閉ループ系の安定化 を行い，その上で周波数応答実験を行い，モデルを導 出した.

図 4 に周波数応答実験により得られたゲインと位相 を四角点で示す，つぎに得られた実験結果をもとに最 小自乗法を用いたカーブフィッティングを行い，モデ ルを導出する. ここではモデルの次数は式 (7) に合わ せた. これより以下のヨー運動モデル $P_{y}$ が得られた.

$$
P_{y}=\frac{61.36}{s(s+1.497)}
$$

ここで $P_{y}$ の周波数特性を図 4 の実線で示す.

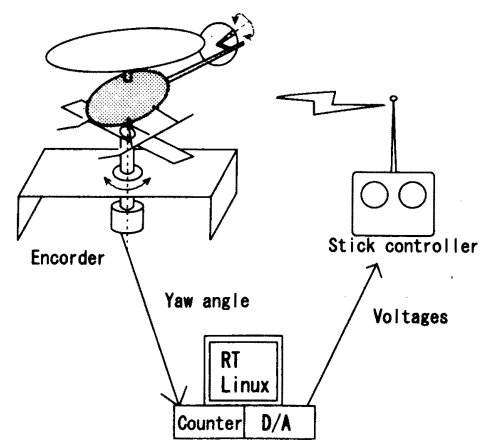

Fig. 3 A schematic diagram of the experimental setup for the identificaiton of the yaw angle dynamics.

つぎに補償器の設計を, LSDP(Loop Shaping Design Procedure) ${ }^{(11)(12)}$ により行う. LSDP は重み関数を用い て制御対象が所望の開ループ特性になるように整形し， 補償器の設計問題を $H^{\infty}$ 制御問題に帰着させて安定化 補償器を設計する手法である. 本稿では性能仕梯とし て追従特性を考虑して, 以下の重み関数 $W_{y}(s)$ を選定
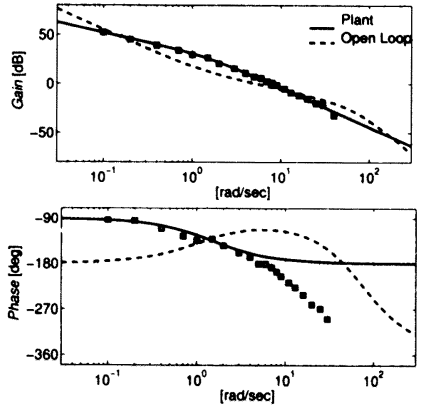

Fig. 4 Yaw angle plant $P_{y}$ and $P_{y} C_{y}$ frequency response.

した.

$$
W_{y}(s)=0.12 \frac{(0.667 s+1)(0.556 s+1)}{0.556 s(0.0133 s+1)^{2}}
$$

$P_{y}$ と設計された補償器からなる開ループ特性を図 4 の破線で示す．低周波ゲインが大きくなっていること から，良好な追従性能が期待できる．なお，補償器の 計算機への実装には，サンプリング時間 $5[\mathrm{~ms}]$ の零次 ホールドで離散化したものを用いる.

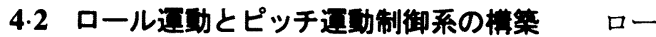
ル運動とピッチ運動モデルを導出するために周波数応 答実験を行う. 図 5 に実験装置の概略図を示す。ここで は，ヨー運動の同定実験噮境とは異なり，ジンバルス タンドを用いる.このジンバルスタンドにより，ロー ル・ピッチ運動間の干涉項が測定可能となる．実験に 使用した計算機，ボードはヨー運動の場合と同様であ る. またサンプリング時間は同様に $1[\mathrm{~ms}]$ である.

ロール・ピッチ運動のモデルは入力を $u_{c}, u_{s}$, 出力 をロール角 $\phi_{F}$, ピッチ角 $\theta_{F}$ とする 2 入力 2 出力系 になる. 解析的にロール・ピッチ運動のモデルを導出 すると，その伝達関数は積分器を有することがわかっ た. このため, 開ループ系での同定実験は困難になる と考え, ヨ一運動の場合と同様, 適当な補償器により 閉ループ系を安定化し，これを用いて同定実験を行う。 

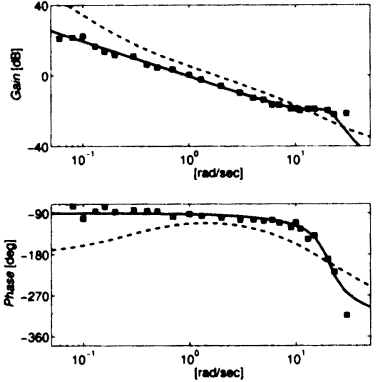

(a) $P_{\phi c}$
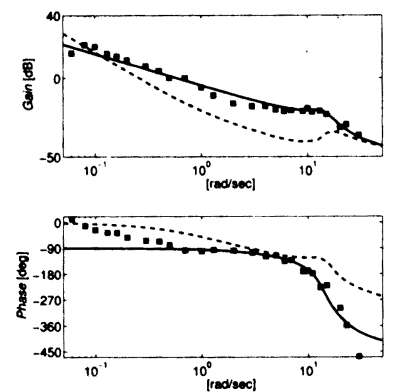

(c) $P_{\theta c}$

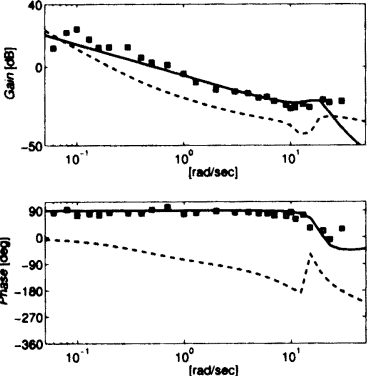

(b) $P_{\phi s}$
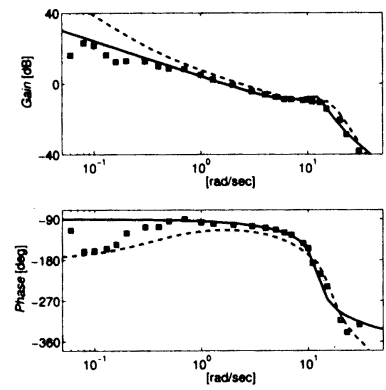

(d) $P_{\theta s}$

Fig. 6 The roll-pitch plant frequency response.

図6に実験より得られたゲインと位相を四角点で示 す.ヨー運動の場合と同様に，得られた実験結果をも とにカーブフィッティングを行って, モデルを導出す る. 図 6 にカーブフィッティングにより得られたロー ル・ピッチ運動モデルの周波数特性を実線で示す.な お, $P_{i j}$ は入力 $u_{j}(j=c, s)$ に対する出力 $i(i=\phi, \theta)$ の 周波数特性を表す.

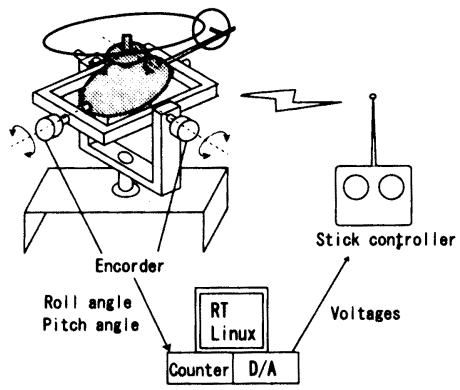

Fig. 5 A schematic diagram of the experimental setup for the identification of the roll-pitch angles dynamics.

つぎに計算量の軽減のため, 導出したモデルの低次元 化を行う．本稿では，低次元化されたモデルに対して， 制御系設計を行う。ここでは Blanced Residualization ${ }^{(12)}$

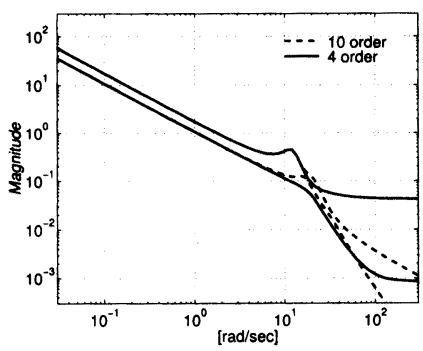

Fig. 7 The model reduction.

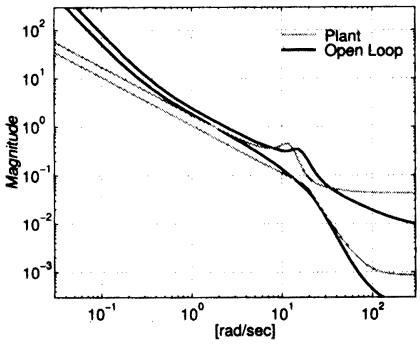

Fig. $8 \sigma$-plot of roll-pitch angles openloop frequency responses.
により低次元化を行う. 図 7 に 10 次のモデル $\hat{P}_{r p}$ と 4 次のモデル $P_{r p}$ の特異值線図をそれぞれ破線と実線 で表す. 図 7 より, $10[\mathrm{rad} / \mathrm{sec}]$ までの 10 次のモデル $\hat{P}_{r p}$ と 4 次のモデル $P_{r p}$ の特異值線図は合っているの がわかる。

つぎにロール・ピッチ運動に対する補償器の設計を LSDPにより行う.ここでは外乱抑制性能を考慮して制 御系設計を行った. 補償器の設計には低次元化したモ デル $P_{r p}$ を用いる.ここでモデル低次元化による影響 が現れないように, 高周波域のゲインを小さくする必 要がある.これらを考虑して, 以下の重み関数 $W_{p r e}(s)$, $W_{\text {pos }}(s)$ を選定した.

$$
W_{\text {pre }}(s)=\left[\begin{array}{cc}
2.4+\frac{0.8}{s} & 0 \\
0 & 1.5+\frac{0.8}{s}
\end{array}\right], W_{\text {pos }}(s)=\left[\begin{array}{cc}
0.9 & 0 \\
0 & 1.0
\end{array}\right]
$$

$P_{r p}$ と設計された補償器からなる開ループ特性を図 8 の黒線で示す．低周波ゲインが大きくなっていること から，良好な外乱抑制性能が期待できる. なお, 補償 器の計算機への実装には, サンプリング時間 $5[\mathrm{~ms}]$ の 零次ホールドで離散化したものを用いる.

\section{3 神姿势運勒の時間応答}

ここでは，4節で設計した補償器を実装して，RCへ リコプタの姿勢制御の実験を行う. 
5.1 制御実験環境 3 軸姿勢運動の制御実験環境 を図 9 , 図 10 に示す。このとき, 角度の測定装置とし てジャイロセンサを用いる、また, 鉛直運動は手動操 縦で一定に保ち, 前後左右の運動は機械的に固定する (図 10 参照).

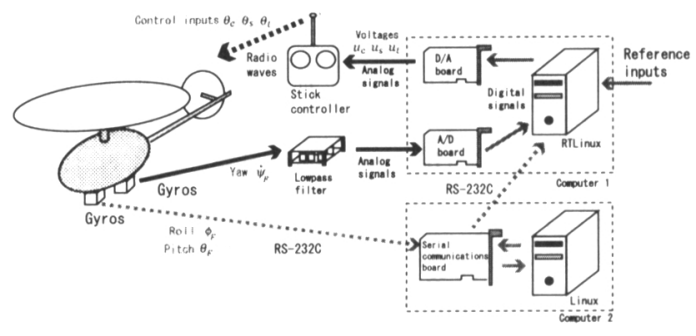

Fig. 9 A schematic diagram of the experimental setup.

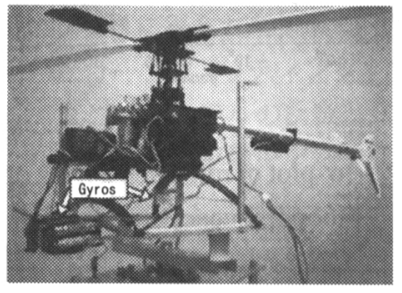

Fig. 10 The RC helicopter. The helicopter equipped with two gyro sensors. The first gyro observes roll and pitch angles. The other supplies yaw angle data.

$5 \cdot 2$ シミュレーション制御系に存在する拘束 条件として, ブレードの回転角度の制約があり，これ により制御入力が $|u| \leq 0.4[\mathrm{~V}]$ に制限される.ここで, 目標値としてロール運動とピッチ運動には 0 を, ヨー 運動には階段状の值を入力する．このときの，拘束条 件が存在する場合としない場合のシミュレーション結 果を，それぞれ黒線と灰色線で図 11 に示寸. 図11(a) より, 拘束条件によって目標值一整定時間が長くなり, かつオーバーシュートがわずかであるが大きくなって いるのがわかる。 また図 11(b) より, 補償器の出力が $\pm 0.4[\mathrm{~V}]$ で飽和していることがわかる。このシミュレー ション結果より, 拘束条件が存在するため, 制御性能 が劣化することがわかる.

$5 \cdot 3$ 実験結果つつぎに RCへリコプタの姿勢制 御の実験結果を示す. 図 12 亿, 実駼結果と拘束条件が 存在するときのシミュレーション結果をそれぞれ黒線 と灰色線で示す, 図 12(a)(b) より, 実験結果とシミュ

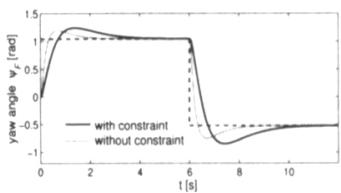

(a) $\psi_{F}$

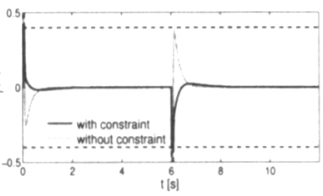

(b) $u_{t}$
Fig. 11 Simulation results of yaw angle motion with and without control constraints.

レーション結果はよく一致することがわかる。これよ り導出したヨー運動モデルは妥当であると考えられ, リファレンスガバナの実装対象として適当であるとい える、また図 12(c)(d)より, ロール運動とピッチ運動 の振幅が小さいことから，外乱抑制性能は良好である といえる.

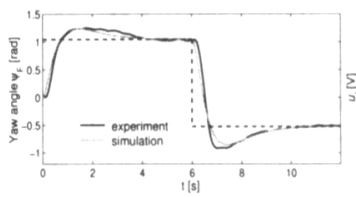

(a) $\psi_{F}$

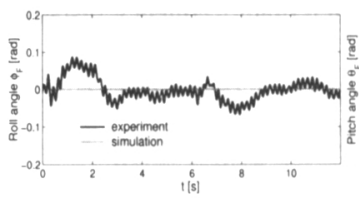

(c) $\phi_{F}$

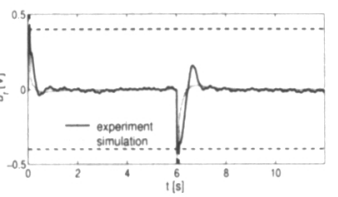

(b) $u_{t}$

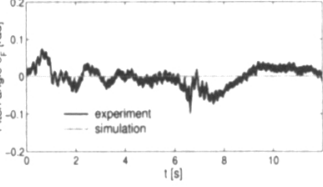

(d) $\theta_{F}$
Fig. 12 Experimental results without referenece governor

\section{6. リファレンスガバナの適用}

ここでは RCヘリコプタに対してリファレンスガバ ナを適用した場合の実験結果を示す.

6.1 シミュレーション ヨー運動制御系に対し て、筆者らが提案したリファレンスガバナ ${ }^{(5)(8)}$ (図 13) を適用する。ここで制御系に対するリファレンスガバ ナを構成するため, 式 (3) より参照入力集合を構成す る.ここでは参照入力集合 $R^{\gamma}$ を規定する $\gamma$ は $\gamma=0.01$ とした。このとき最大出力許容集合 $O_{\infty}^{\gamma}$ は 1004 本の 線形拘束式で規定される。これよりリファレンスガバ ナを付加したときのシミュレーション結果を示す.

図 14 に, リファレンスガバナを適用した場合と適 用しない場合のシミュレーション結果を，それぞれ黒 線と灰色線で示す. 図 14(a) より, リファレンスガバ ナを適用することで, 目標值の整定時間は短くなり, 
かつオーバーシュートが小さくなっているのがわかる. つまり制御性能が改善されていることがわかる。また 図 14(b)より，拘束条件が達成されているのがわかる.

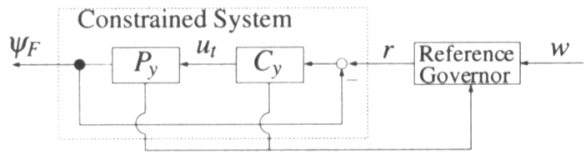

Fig. 13 Reference governor

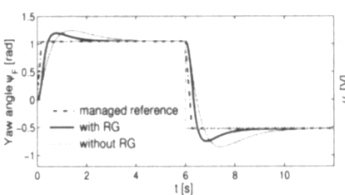

(a) $\psi_{F}$

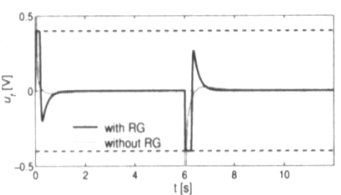

(b) $u_{t}$
Fig. 14 Simulation results with the reference governor proposed by the authors ${ }^{(5)(8)}$.

6.2 実験結果参照入力の整形を行う計算, 式 (6b), (6a) は線形計画問題に帰着される.この実験で は線形計画問題を解くソルバを用いた場合, 制約式の 数が多いため, サンプリング時間 $5[\mathrm{~ms}]$ 内で計算を終 えることはできなかった。そこで本稿では, 式 (6b), (6a) はスカラー変数の線形計画問題であることに着目 して, アルゴリズムを以下のように変形した.

リファレンスガバナアルゴリズム 2

$$
\begin{aligned}
& \text { data: } x(t) \in \mathbb{R}^{n} \text { and } w(t) \in \mathbb{R} \\
& \bar{r}_{\text {max }}=\min _{i=1, \cdots, s, b_{i}>0} \frac{a_{i}}{b_{i}} \\
& \bar{r}_{\text {min }}=\max _{i=1, \cdots, s, b_{i}<0} \frac{a_{i}}{b_{i}} \\
& \quad \bar{r}=\left\{\begin{array}{l}
w(t) \text { if } \bar{r}_{\text {min }} \leq w(t) \leq \bar{r}_{\text {max }} \\
\bar{r}_{\text {max }} \text { if } \bar{r}_{\text {max }}<w(t) \\
\bar{r}_{\text {min }} \text { if } w(t)<\bar{r}_{\text {min }}
\end{array}\right. \\
& \text { if } w(t) \in R(\bar{r}): r(t)=w(t) \\
& \text { else if } w(t)>\bar{r}+\gamma: r(t)=\bar{r}+\gamma \\
& \text { elser } \quad: r(t)=\bar{r}-\gamma
\end{aligned}
$$

ただし $, a=m-M x(t), \quad b=-M(I-A)^{-1} B$ で, $a_{i}, b_{i}$ はそれぞれ $a, b$ の $i$ 行目の要素を表す。このように変 形することで，簡単にかつ効率的に参照入力を整形す ることができる.

筆者らが提案したリファレンスガバナ ${ }^{(5)(8)}$ を適用し た場合の実験結果を図 15 に黒線で示す。図 15(a), (b) より,リファレンスガバナを適用することで, 収束が
速くなり，また飽和が回避されているのがわかる。し かしながら，図 14(a)のシミュレーション結果に比心゙ て，オーバーシュートが大きくなっているのがわかる。

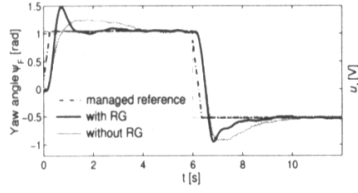

(a) $\psi_{F}$

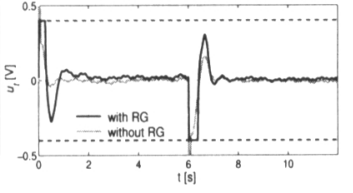

(b) $u_{t}$

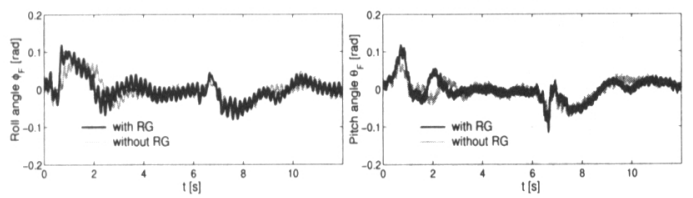

(c) $\phi_{F}$

(d) $\theta_{F}$

Fig. 15 Experimental results with the reference governor proposed by the authors ${ }^{(5)(8)}$.

つぎに Gilbert らにより提案されたリファレンスガ バナ(2) を適用した場合の実験結果を図 16 に黒線で示 す.ここで筆者らの方法と比較するため, 図 15(b) と 図 16(b) を拡大したものを図 17 に示す. 図 17 より, Gilbert らの方法を用いた場合，わずかにであるが拘束 条件を破っているのわかる. また図 15 と同様に大き なオーバーシュートが生じているのが図 16(a) よりわ かる。

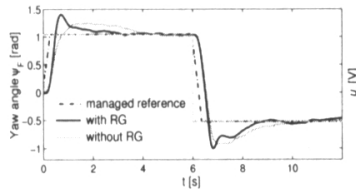

(a) $\psi_{F}$

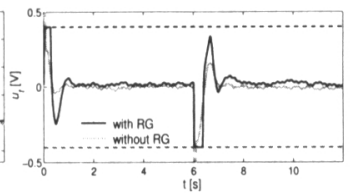

(b) $u_{t}$

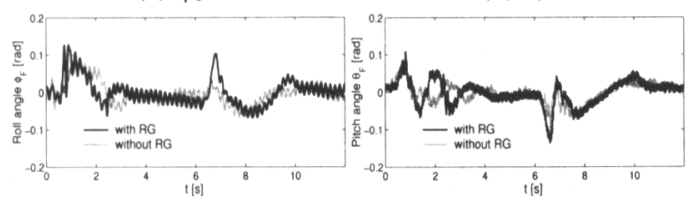

(c) $\phi_{F}$

(d) $\theta_{F}$

Fig. 16 Experimental results with the reference governor proposed by Gilbert et $a^{(2)}$.

以上の実験結果より, リファレンスガバナを利用し た制御系は，拘束条件を達成しつつ，目標值へ追従す ることがわかった．実験では，アルゴリズムによって は拘束条件をわずかに破るという結果になった。

つぎに大きなオーバーシュートが生じた原因につい 


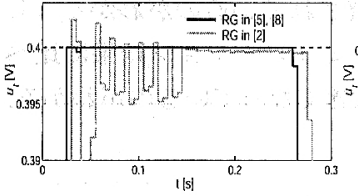

(a) $u_{t}(0 \leq t \leq 0.3)$

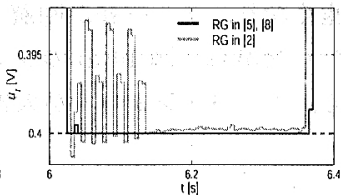

(b) $u_{t}(6 \leq t \leq 6.4)$
Fig. 17 The control inputs in experiments.

て考察する.

本稿では，むゃだ時間が原因の一つであると考え，そ の影響を検証する.ここでは，ヨー運動モデルの同定 実験からむだ時間の長さを推定し，むだ時間を含めた モデルを導出する。つぎに導出したモデルを用いてシ ミュレーションを行う.

ヨー運動モデルの同定の実験結果から，むだ時間の 長さを推定する。これより以下のむだ時閒を含んだ ヨー運動モデル $P_{d e l}$ を導出した.

$$
P_{\text {del }}=\frac{61.36}{s(s+1.497)} e^{-0.066 s}
$$

ヨ一運動モデル $P_{d e l}$ の周波数特性を図 18 に示す. 図 18 より高周波の位相まで実験結果と一致しているの がわかる.
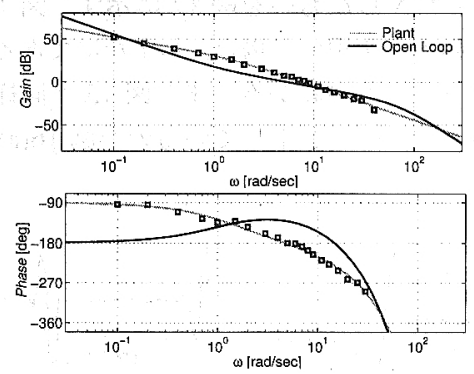

Fig. 18 Yaw angle plant $P_{y}$ and $P_{y} C_{y}$ frequency response.

モデル $P_{d e l}$ を用いた場合のシミュレーション結果と 図 15 の実験結果を図 19 で比較する.図 19 より,む

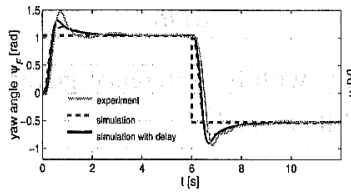

(a) $\psi_{F}$

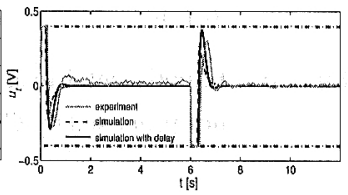

(b) $u_{t}$
Fig. 19 Simulation results using the model $P_{d e l}$.

だ時間を含めたモデルがより実験結果に近い挙動を表 しているのがわかる.これより，実験において大きな
オーバーシュートが生じた原因の一つは，モデルの導 出時に考慮しなかったむだ時閒と考えられる。

\section{7.お りりに}

本稿では, RC ヘリコプタに対してリファレンスガ バナを適用し，その実験結果を示した．実験では，リ ファレンスガバナを適用することで，拘束条件は達成 され，かつ良好な忘答が得られることが示された。し かしながら，シミュレーションでは現れなかった大きな オーバーシュートが锥測された．この大きなオーバー シュートが生じた原因の一つは，モデルの導出時に考 慮しなかったむだ時間と考えられる，むだ時閒を考虑 した制御系設計,リファレンスガバナの構成法は今後 の課題である.

\section{文献}

(1) E. G. Gilbert, Linear Control Systems with Pointwisein-Time Constraints: What Do We Do About Them ?, Proceedings of the 1992 American Control Conference, (1992), pp. 2565.

(2) E. G. Gilbert, I. Kolmanovsky and K. T. Tan, Discretetime Reference Governors and the Nonlinear Control of Systems with State and Control Constraints, International Journal of Robust and Nonliear Control, 5, (1995), pp. 487-504.

(3) R. H. Miller, I. Kolmanovsky, E. G. Gilbert and P. D. WAshabaugh, Control of Constrained Nonlinear Systems; A Case Study, IEEE Control Systems Magazine, 20, 1, (2000), pp. 23-32.

(4) A. Bemporad and E. Mosca, Fulfilling Hard Constraints in Uncertain Linear Systems by Reference Managing, Automatica, 34, 4, (1998), pp.451-461.

(5) 平田, 藤田, 参照入力集合の連結にもとづく拘束シス テムの制御，システム制御情報学会論文誌，12，10， (1999), pp. 586-595.

（6）平田，小木曾, 拘束条件の達成を考慮したリファレンス ガバナの実現, システム制御情報学会論文誌, 14, 11, (2001), pp. 554-559.

（7）小木曽, 峯村, 平田, リファレンスガバナによる拘束シ ステムの制御検証実験，日本機械学会論文集 C 編，69， 681, (2002), pp. 1238-1246.

(8) 大原, 平田, 参照入力集合のパラメトリゼーションに もとづくリファレンスガバナの実現と実験による検証, 第 3 回制御部門大会, (2003), pp. 379-382.

（9）杉江，山本，状態および入力の制約を考虑した閉ルー プ系の目標值生成, 計測自動制御学会論文誌, 37,9 , (2001), pp. 849-855.

(10) 大山, 山野, 古田, ラジコンヘリコプタのモデリング と制御, 計測自動制御学会論文集, $20,4,(1984), p p$. 70-76.

(11) D. MacFarlane and K. Glover, A Loop Shaping Design Procedure Using $H_{\infty}$ Synthesis, IEEE Transactions on Automatic Control, 37, 6, (1992), pp. 759-769.

(12) S. Skogestad and J. Postlethwiaite, Multivariable Feedback Control -Analysis and Design-, Jhon Wiley \& Sons Ltd, (1996). 